\title{
Prevalence and herd-level risk factors of bovine tuberculosis in the State of Santa Catarina
}

\section{Prevalência e Fatores de Risco da Tuberculose Bovina no Estado de Santa Catarina}

\author{
Flávio Pereira Veloso우 Karina Diniz Baumgarten²; Ana Lourdes Arrais de \\ Alencar Mota ${ }^{3}$; Fernando Ferreira ${ }^{4}$; José Soares Ferreira Neto ${ }^{4}$; \\ José Henrique Hildebrand Grisi-Filho4; Ricardo Augusto Dias"; Marcos Amaku*; \\ Evelise Oliveira Telles"; Vítor Salvador Picão Gonçalves ${ }^{5 *}$
}

\begin{abstract}
With the aim of supporting the strategic planning of the National Program for Control and Eradication of Brucellosis and Tuberculosis, different Brazilian states have been conducting cross-sectional studies, coordinated by the Ministry of Agriculture, Livestock, and Supply and with scientific support from the University of São Paulo and the University of Brasilia. In Santa Catarina, the State Animal Health Agency (CIDASC) conducted a study on bovine tuberculosis (TB) prevalence and assessment of risk factors in 2012. The state was divided into five regions and, in each region, independent sampling was performed in two steps: (i) cattle herds with reproductive activity were randomly selected; and (ii) in each herd, a sample of females aged 24 months or older underwent the intradermal comparative tuberculin test. A questionnaire was used to collect data on production characteristics and management practices that could be associated with the tuberculosis infection. Herd prevalence of bovine TB was $0.50 \%$ (95\% confidence interval [CI]: $0.074-0.93 \%)$ while the prevalence of TB in adult females was $0.06 \%$ (95\% CI: $0-0.12 \%$ ). No significant difference in the prevalence of infected herds and of positive females was observed among the five regions. The logistic regression model revealed that herds with 19 or more females showed an odds ratio (OR) of 7.68 (95\% CI: 1.22-48.39) compared to smaller herds, while dairy herds presented an OR of 10.43 (95\% CI: 2.00-54.25) relative to beef or dual-purpose herds. The results suggest that dairy herds, in which animals are kept in partial or total confinement, and larger herds, which tend to acquire animals more often, are at a higher risk of bovine TB. Given the low prevalence and the type of higher-risk properties, a bovine TB surveillance system should be targeted at the state's dairy basins, particularly the western region that accounts for the major industries and more intensive dairy farms.
\end{abstract}

Key words: Bovine tuberculosis. Brazil. Herd-level risk factors. Prevalence. Santa Catarina.

\footnotetext{
${ }^{1}$ Médico Veterinário, Discente de Doutorado em Saúde Animal, Universidade de Brasília, UnB, Companhia Integrada de Desenvolvimento Agrícola de Santa Catarina, CIDASC, Florianópolis, Brasil. E-mail: fveloso@cidasc.sc.gov.br

${ }^{2}$ Médica Veterinária, Discente de Doutorado em Ciência, Universidade de São Paulo, USP. Companhia Integrada de Desenvolvimento Agrícola de Santa Catarina, CIDASC, Florianópolis, Brasil. E-mail: kdiniz@cidasc.sc.gov.br

${ }^{3}$ Médica Veterinária, Dr ${ }^{\mathrm{a}}$ em Saúde Animal, Faculdade de Agronomia e Medicina Veterinária, UnB, Brasília, Brasil. E-mail: analourdes@unb.br

${ }^{4}$ Profs., Faculdade de Medicina Veterinária e Zootecnia, Universidade de São Paulo, USP, São Paulo, SP, Brasil. E-mail fernando@ vps.fmvz.usp.br; jsoares@vps.fmvz.usp.br; grisi@vps.fmvz.usp.br; dias@vps.fmvz.usp.br; amaku@vps.fmvz.usp.br; evelise@ vps.fmvz.usp.br

5 Prof., Faculdade de Agronomia e Medicina Veterinária, UnB, Brasília, Brasil. E-mail: vitorspg@unb.br

* Author for correspondence
} 


\section{Resumo}

Com o objetivo de apoiar o planejamento estratégico do Programa Nacional de Controle e Erradicação da Brucelose e Tuberculose, diferentes estados brasileiros têm realizado estudos transversais coordenados pelo Ministério da Agricultura, Pecuária e Abastecimento, com o apoio científico da Universidade de São Paulo e da Universidade de Brasília. Em Santa Catarina, em 2012, a Companhia Integrada de Desenvolvimento Agrícola (CIDASC) realizou o estudo sobre a prevalência e fatores de risco da tuberculose bovina (TB). O Estado foi dividido em cinco regiões e, em cada uma delas, foi realizada uma amostragem independente em duas etapas: (i) propriedades com atividade reprodutiva foram selecionadas aleatoriamente; (ii) em cada propriedade, uma amostra de fêmeas com idade igual ou superior a 24 meses foi submetida ao teste tuberculínico intradérmico comparativo. Um questionário foi utilizado para recolher dados sobre as características de produção e práticas de gestão que poderiam estar associados com a infecção tuberculosa. A prevalência de focos de tuberculose bovina foi de 0,50\% (95\% intervalo de confiança [CI]: 0,074-0,93\%), enquanto a prevalência de TB em animais foi de $0,06 \%$ (IC 95\%: 0-0,12\%). Não foi observada diferença significativa na prevalência de focos ou animais entre as cinco regiões. O modelo de regressão logística revelou que rebanhos com 19 ou mais vacas apresentaram um odds ratio (OR) de 7,68 (IC 95\%: 1,22-48,39) em comparação com rebanhos menores, enquanto rebanhos leiteiros apresentaram um OR de CI 10,43 (95\%: 2.00- 54,25) em relação aos rebanhos de corte ou de duplo propósito. Os resultados sugerem que os rebanhos leiteiros, em que os animais são mantidos em confinamento parcial ou total, e rebanhos maiores, que tendem a adquirir animais mais frequentemente, estão sob maior risco de tuberculose bovina. Dada a baixa prevalência e o tipo de propriedades sob maior risco, um sistema de vigilância para tuberculose bovina deve ser orientado para as bacias leiteiras do Estado, em especial a região oeste, onde encontram-se as principais indústrias e a maioria das explorações leiteiras intensivas.

Palavras-chave: Brasil. Fatores de risco. Prevalência. Santa Catarina. Tuberculose bovina.

\section{Introduction}

Bovine tuberculosis (TB) affects herd health, profitability, and trade; can undermine years of genetic refinement; and can negatively influence the productivity of the affected cattle (SKUCE et al., 2012). The main route of introduction of disease into a herd is the acquisition of infected animals, which is strongly influenced by production unit characteristics such as the type of farm, herd size, population density, and husbandry and sanitary practices (BRASIL, 2006). Properties with more intensive livestock farming have a greater tendency to move animals, and this practice promotes the spread of the disease (LIVINGSTONE et al., 2006).

Bovine TB poses a risk to public health even if preventive actions are taken to prevent its transmission to humans. However, some authors suggest that the main concerns regarding bovine TB control are related to its commercial implications (SKUCE et al., 2012). Therefore, bovine TB control is of great relevance to Brazil, because the livestock industry is very important for the country.
With an aim to organize the prevention of bovine $\mathrm{TB}$ and reduce its incidence and prevalence, in 2001, the Ministry of Agriculture, Livestock, and Supply (MAPA) created the National Program for Control and Eradication of Brucellosis and Tuberculosis (PNCEBT) (BRASIL, 2001, 2004). As part of the activities implemented by PNCEBT, studies were carried out on TB prevalence in 12 states, which hold $73 \%$ of the Brazilian cattle population (BAHIENSE et al., 2016; BARBIERI et al., 2016; DIAS et al., 2016; GALVIS et al., 2016; GUEDES et al., 2016; LIMA et al., 2016; NÉSPOLI et al., 2016; QUEIROZ et al., 2016; RIBEIRO et al., 2016; ROCHA et al., 2016; SILVA et al., 2016; VENDRAME et al., 2016). Intensive milk production, associated with larger herds and with higher technological level, was indicated by those studies as risk factors for bovine TB. This reinforces the need for ongoing surveillance of the disease in the main dairy basins and brings about opportunities for herd-level accreditation schemes. 
Santa Catarina is a state characterized by small farms. The state has an area of $95,736,165 \mathrm{~km}^{2}$ (IBGE, 2014a). In swine production, it stands out as the largest exporter of pork in Brazil, with a volume of almost $25 \%$ of national exports, and in poultry production, it occupies the second place on the list of national exporters of chicken meat (IBGE, 2014b). In 2012, Santa Catarina held a cattle herd of 4,072,960 heads (IBGE, 2014c) in a territory recognized as free from foot-and-mouth disease, where vaccination is not practiced, by the World Organization for Animal Health (OIE) (OIE, 2014).

Neves (2014) reported that Santa Catarina cattle herds have a median of 10 and an average of 28 animals, and that farms with up to 30 animals represented $73.7 \%$ of the beef herds and $84.2 \%$ of the dairy or dual-purpose herds. However, despite the existing small herd sizes, the state is the fifth largest national producer of milk (EMBRAPA, 2012). The Santa Catarina dairy production in 2011 reached approximately 2.5 billion liters, equivalent to about $7.8 \%$ of Brazilian diary production. According to Neves (2014), the state is characterized by marked regional production diversity. While dairy herds are predominant in the western region, dual-purpose herds are predominant in Greater Florianópolis and southern Santa Catarina, and there is a balance between the production purposes of herds in Vale do Itajaí. In the northern and Serrana regions of the state, beef cattle are the most common. The same author pointed out that $33.21 \%$ of the dairy or dual-purpose herds in Santa Catarina follow the semi-confinement system, and that although manual milking is predominant in the state, only $32.7 \%$ of farmers still use this practice in the western region. In this region, $12 \%$ of the sampled properties had a milking parlor and $48.7 \%$ used artificial insemination. These data reveal the incorporation of technology in the Santa Catarina production system, particularly in the western region dominated by dairy activity.

Data on bovine TB presented by the Conselhos Regionais de Medicina Veterinária of Paraná, Santa Catarina, and Rio Grande do Sul (2009) indicate that 82,476 animals (approximately $2.22 \%$ of the state herd) were tested in Santa Catarina in 2008. Of these, 853 tested positive for TB, i.e., $1.03 \%$ of the animals tested. These animals were part of the 196 infected herds detected in that year. Although such data provide evidence of the presence of TB in Santa Catarina, it is not representative of the state's cattle herd. Hence, we carried out a random sample survey to estimate the prevalence and geographical distribution of cattle herds infected with TB in Santa Catarina State, and to identify the types of production and management practices that may be associated with higher disease risk.

\section{Materials and Methods}

This cross-sectional random survey was conducted in Santa Catarina State to estimate the prevalence and investigate herd-level risk factors for bovine TB. The target population comprised all state farms with cattle production, except those without adult animals used for reproductive purposes. This study was part of a cooperative project between MAPA and the Santa Catarina Animal Health Agency (CIDASC), the Collaborator Centre in Animal Health of the University of São Paulo, and the Veterinary Epidemiology Laboratory at the University of Brasilia.

\section{Diagnosis of $T B$}

We applied the intradermal comparative cervical tuberculin test (ICCT), as described in the PNCEBT technical regulations (BRASIL, 2004). Animals with inconclusive test results were retested with a minimum interval of 60 days between tests. An animal was considered positive if it had two consecutive inconclusive test results.

\section{Sampling}

The state of Santa Catarina was divided into five distinct regions, as shown in Figure 1, according to the production system characteristics, animal 
management, production purposes, mean herd size, and marketing system. The classification of the sampling regions was similar to that established by the Brazilian Institute for Geography and Statistics (IBGE) for Brazilian mesoregions: Region 1-“Serrana"; Region 2-Greater "Florianópolis" and southern Santa Catarina; Region 3-western Santa Catarina; Region 4-northern Santa Catarina; and Region 5-"Vale do Itajaí." This classification has been used extensively by the state animal health authorities for regionalization of health initiatives.

Figure 1. Division of Santa Catarina State into regions according to production and trade characteristics.

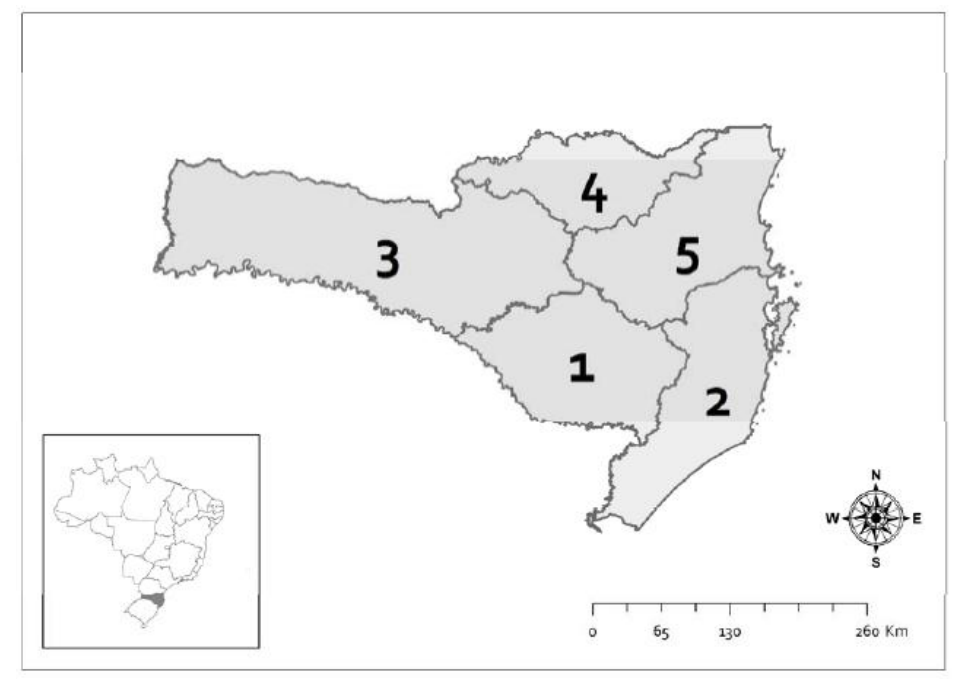

Sampling was conducted in all 293 municipalities of the state in two stages. (i) In each region, properties with reproductive activity, which were the primary sampling units, were randomly selected. (ii) In the main herds of these properties, females aged 24 months or older were sampled; these were the secondary sampling units.

The sample size was calculated according to the formula described by Petrie and Watson (2009), using Epitools ${ }^{\circledR}$ (SERGEANT, 2014). The minimum number of primary sampling units (herds) per region was 292, assuming a simple random sampling method and considering the following parameters: estimated herd prevalence $(\mathrm{P}=5 \%)$, desired precision $( \pm 2.5 \%)$, and confidence level (95\%).

For calculating the number of secondary sampling units, we assumed a $15 \%$ within-herd prevalence, based on information provided by researchers who conducted previous studies on bovine TB in Minas Gerais, Bahia, and Paraná. Simulations were performed using Epitools ${ }^{\circledR}$ (SERGEANT, 2014) for different herd sizes, number of animals sampled, and different cut-off points to determine positive herds. We adopted a criterion to obtain aggregate sensitivity and specificity of at least $90 \%$ at the herd level. The sensitivity and specificity estimated for the ICCT were $77.5 \%$ and $99.5 \%$, respectively, based on the findings of Lôbo (2008), who used a PERT distribution to model ICCT characteristics from values found in the scientific literature.

Females that were about to give birth in 15 days or had given birth 15 days before testing (BRASIL, 2006) were excluded because of an increased risk of false-negative results during this period. The animals were sampled through a simple random sampling procedure (PETRIE; WATSON, 2009) involving the use of a table of random numbers. Sampling of animals was performed as follows: in herds of up to 
20 females aged 24 months or older, all females of the same age were tested; in herds with more than 20 and up to 99 females aged 24 months or older, 20 females of the same age were tested; and in herds with more than 99 females aged 24 months or older, 40 females of the same age were tested. In herds with up to 99 females eligible for testing, detection of at least one test-positive animal led to the herd being classified as positive. Herds with more than 99 females were classified as positive only if there were at least two test-positive animals among 40 tested females. Table 1 summarizes the census data and total sample size of herds and animals for each production region.

Table 1. Census data of the bovine population in the state of Santa Catarina in 2012, grouped by production region.

\begin{tabular}{ccccc}
\hline \multirow{2}{*}{ Region } & \multicolumn{2}{c}{ Herds with reproductive activity } & \multicolumn{2}{c}{ Females $\geq 24$ months } \\
\cline { 2 - 5 } & Population & Sampled & Population & Sampled \\
\hline 1 & 15,373 & 310 & 283,064 & 2,977 \\
2 & 40,975 & 328 & 275,401 & 1,587 \\
3 & 86,598 & 368 & $1,107,212$ & 3,857 \\
4 & 12,826 & 307 & 96,917 & 1,769 \\
5 & 43,402 & 340 & 266,871 & 1,460 \\
\hline Total & 199,174 & 1,653 & $2,029,465$ & 11,650 \\
\hline
\end{tabular}

\section{Operationalization}

Questionnaire application and animal tests were conducted from June to December 2012 by veterinarians of the Integrated Agricultural Development Company of Santa Catarina. The professionals involved in the study received training to standardize testing methods and questionnaires, and a manual containing all procedures was made available to them. The herds were given individual codes, and all properties had their geographical coordinates (degrees, minutes, and decimal seconds) as well as altitude recorded. An initial visit to the randomly selected properties was made.

During the visit, the questionnaire was applied to collect data for the investigation of risk factors. The questions were related to the productive characteristics of the sampled herds, general production practices, and health management, as well as some aspects of public health interest, as described below:

a) Type of production-categories: "beef cattle," "dairy cattle," or "dual-purpose herds." Beef herds were classified according to the main production purposes of breeding, rearing, and fattening; both full and partial production cycles were considered. The main goal was fattening and slaughter of animals for meat production. In these properties, the presence of dairy cattle for on-farm milk consumption did not prevent the herd from being characterized as beef type.

Herds classified as dairy cattle were those whose main activities were milk production, regardless of the destination of the milk produced-consumption, sale, or processing. In the dual-purpose category, the herds included were dedicated to both meat production, in full or partial cycle of breeding, rearing, and fattening, and to dairy activity. In this category, the beef cattle and dairy cattle shared environments and facilities.

In herds classified as dairy or dual-purpose, the number of milkings performed each day was recorded as "no milking," "one milking per day," or "two milkings per day." The method of milking was recorded as "manual milking," "mechanical milking with bucket," or "mechanical milking in parlor."

b) Farming type-categories: "confined," "semiconfined," or "extensive." The herds under the category "confined" were those in which the animals 
were raised and fed in a systematic and controlled manner, and in limited and small spaces. "Semiconfined" indicated that the herds were raised on pastures, and were provided with supplemental feeding throughout or for part of the year. In herds of the "extensive" category, the animals were raised exclusively on pastures, and were optionally provided with protein concentrate and/or mineral salt.

c) Herd size-Population of cattle on the properties were categorized as: "castrated males," "males between 0 and 6 months," "males between 6 and 12 months," "males between 12 and 24 months," "males over 24 months," "females between 0 and 6 months," "females between 6 and 12 months," "females between 12 and 24 months," and "females over 24 months."

d) Existence of other domestic species on the property-options: "equine," "swine," and "poultry."

e) Existence of free-living wild species on the property-options: "cervids," "capybaras," "marsupials," "wild felines," and "wild primates."

f) Dichotomous variables-options "yes" or "no": "TB test required before purchasing animals," "pasture rental at any time of the year," "common pastures with other properties," "acquisition of females or males for reproduction," "sale of females or males for reproduction," "sharing of water sources or troughs with other properties," "sharing inputs with other properties," "sharing equipment with other properties," "sharing of employees with other properties," "existence of flooded areas in the property," "existence of areas in which animals gather on the property," and "existence of areas for cattle resting while travelling."

g) Property classification-categories: "Classic Rural," "Indian Village," "Settlement," and "Urban Periphery."

Dohoo et al. (2010) drew attention to the limitations of cross-sectional studies in which the goal was to observe potential risk factors. Rothman et al. (2008) explained that one of the limitations was the difficulty in determining the temporal sequence of the occurrence of events. Therefore, it has to be emphasized that the analysis of variables described in the present study and their association with the occurrence of TB was not aimed at establishing causal links, but rather attempts to identify herdprofiles and cattle production practices statistically associated with the increased risk of bovine TB.

\section{Statistical analyses}

Estimates of the herd-level and animal-level prevalence were performed using STATA $\AA$ software version 12 (STATA, 2014). As a simple random sample of herds was performed within each region, the estimated herd prevalence was based on the ratio between herds classified as positive in the sample and the total sampled herds in the region. To estimate herd prevalence at the state level, it was necessary to consider that the sampling was not proportional to the number of herds in each region; therefore, samples from each region had different weights in the calculation of state prevalence.

According to Dohoo et al. (2010), the most common method of obtaining sample weights is to use the inverse of the sample selection probability. The results reflect the number of individuals in the population that each individual in the sample represents. Thus, for the calculation of herd prevalence at the state level, a weighting with the weight $\mathrm{P}_{1}$ was applied to each sampled herd/ property in each region:

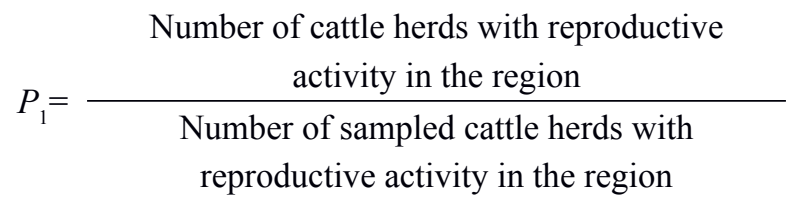

To estimate the prevalence of TB in cows aged 24 months or older, the cluster sampling conducted in two stages was considered. The clusters were the 
herds within which cows aged 24 months or older were sampled. Thus, to calculate the state prevalence of these animals, a weighting was performed with $\mathrm{P}_{2}$ considered as the weight of each cow aged 24 months or older sampled in relation to its herd and to the respective region:

$$
\begin{gathered}
P_{2}=\frac{\text { cows } \geq 24 \text { months in the herd }}{\text { cows } \geq 24 \text { months in the region }} \mathrm{X} \\
\frac{\text { cows } \geq 24 \text { months sampled in the herd }}{\text { cows } \geq 24 \text { months sampled in the region }}
\end{gathered}
$$

The prevalence calculations were performed using STATA $\AA$ software, version 12 (module: Statistics $\rightarrow$ Summaries, tables, and tests $\rightarrow$ Proportion). The prevalence in adult cows considered a multistage sampling ([aba]: SE/Cluster $\rightarrow$ Survey data estimation $\rightarrow$ Survey settings $\rightarrow$ Number of stages $\rightarrow 2$ : first stage, properties, second stage, cows aged 24 months or older). The confidence intervals (CIs) of the herd prevalence in each region were obtained using the Exact Binomial Distribution (module: Statistics $\rightarrow$ Summaries, tables, and tests $\rightarrow$ Confidence Intervals) (STATA, 2014).

The putative risk factors were identified using the Chi-square univariable analysis (PETRIE; WATSON, 2009). Variables with p-value $\leq 0.20$ were selected for the multiple logistic regression model using the hierarchical backward elimination procedure. This was performed in two formats, as suggested by Hosmer et al. (2013). (i) Model-based format: this assumes that simple random sampling was used and is applied to select variables that form the final model, to evaluate model fit using the maximum likelihood ratio, and to evaluate the discriminatory power of the model. (ii) Designbased format: this considered the weight of each sampled property in the five sampling regions, which is more appropriate for population inference of the magnitude of risk factors.
For developing the logistic regression model in the model-based format and evaluation of its discriminatory capacity through a receiver operating characteristics (ROC) curve, we used STATA ${ }^{\circledR}$ software, version 12 (module: Statistics $\rightarrow$ Binary outcomes $\rightarrow$ Logistic Regression (reporting odds ratios) $\rightarrow$ [aba] Model: Dependent variable $\rightarrow$ Independent variables $\rightarrow$ submit $\rightarrow$ [command line] 1roc) (STATA, 2014).

For developing the logistic model in the designbased format, we used STATA ${ }^{\circledR}$ software, version 12 (module: Statistics $\rightarrow$ Binary outcomes $\rightarrow$ Logistic Regression (reporting odds ratios) $\rightarrow \mathrm{SE} /$ Robust $\rightarrow$ Survey data estimation $\rightarrow$ Survey settings $\rightarrow$ [aba] Main $\rightarrow$ Number of stages $\rightarrow$ Stage 1: properties $\rightarrow$ Strata: regions $\rightarrow$ [aba] Weights $\rightarrow$ Sampling weight variable: weight assigned to each property by region $\rightarrow$ [aba] Model: Dependent variable $\rightarrow$ Independent variables) (STATA, 2014).

\section{Results}

Of the 11,650 animals sampled in Santa Catarina, nine tested positive for TB. These animals were from eight of the 1,653 sampled herds as in only one herd two animals tested positive. Figure 2, prepared using the QuantumGis ${ }^{\circledR}$ software (QUANTUM GIS DEVELOPMENT TEAM, 2012), graphically represents the location of the TB-positive herds. Tables 2 and 3 show the herd-level and animal-level TB prevalence in the State. Prevalence in adult females observed in the present study indicates that the specificity of ICCT was greater than that assumed by Lôbo (2008) and was very close to $100 \%$. This finding can be utilized in future studies to determine the sample size of animals per herd. 
Figure 2. Spread of herds that tested positive for tuberculosis.

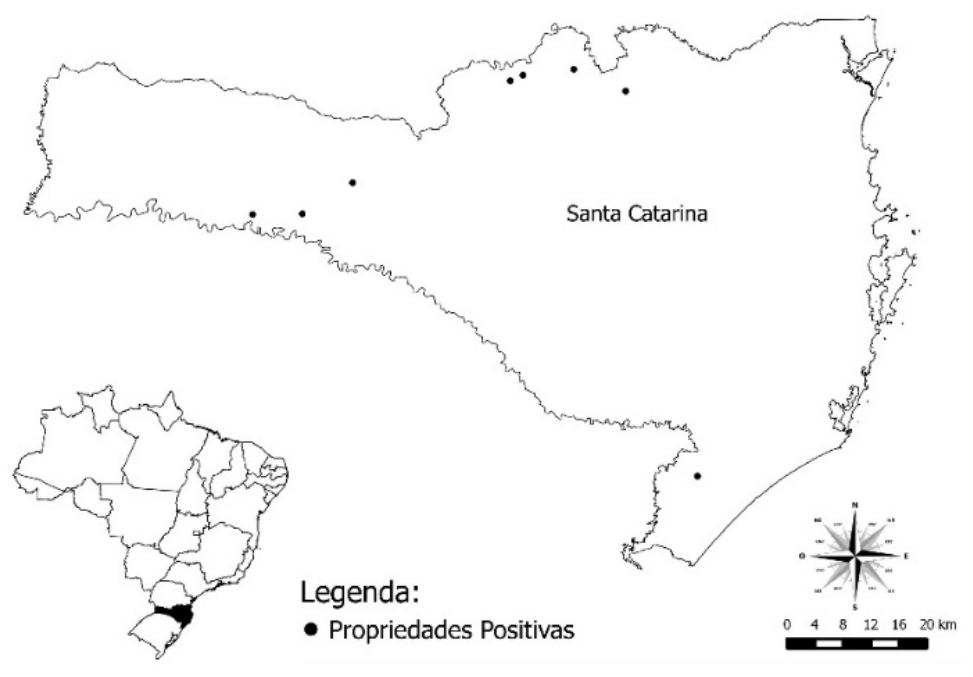

Table 2. Apparent herd prevalence of bovine tuberculosis in Santa Catarina, grouped by region.

\begin{tabular}{ccccc}
\hline Region & No. of positive herds & Apparent prevalence (\%) & \multicolumn{2}{c}{ 95\% Confidence Interval (\%) } \\
\hline 1 & 0 & 0.00 & 0.00 & 1.18 \\
2 & 1 & 0.30 & 0.00 & 1.69 \\
3 & 3 & 0.82 & 0.17 & 2.36 \\
4 & 4 & 1.30 & 0.35 & 3.30 \\
5 & 0 & 0.00 & 0.00 & 1.08 \\
\hline Total & 8 & 0.50 & 0.074 & 0.93 \\
\hline
\end{tabular}

Table 3. Prevalence of bovine tuberculosis among females ( 24 months or older) in Santa Catarina, grouped by region.

\begin{tabular}{ccccc}
\hline Region & No. of positive animals & Apparent prevalence (\%) & $95 \%$ Confidence Interval (\%) \\
\hline 1 & 0 & 0.00 & - & - \\
2 & 1 & 0.04 & 0.00 & 0.13 \\
3 & 3 & 0.08 & 0.00 & 0.19 \\
4 & 5 & 0.19 & 0.00 & 0.43 \\
5 & 0 & 0.00 & - & - \\
\hline Total & 9 & 0.06 & 0.00 & 0.12 \\
\hline
\end{tabular}

Prevalence was very low which limited the number of cases for some variables included in the questionnaire. This, in turn, made it necessary, to regroup some of the variables into only two categories to conduct the logistic regression analysis. Regarding the type of production, the category "extensive" was compared to "confined or semi-confined," whereas for the production purpose, the category "dairy" was compared to "beef or dualpurpose."

With regard to herd size, the herds were divided into two categories: "herds with up to 18 females" and "herds with 19 or more females." This was done because the third quartile of the distribution of herd size was 18 females, highlighting the fact that, in Santa Catarina, a vast majority of the properties 
have small cattle herds. Thus, herds with 19 or more females, which account for only $25 \%$ of the properties, are considered relatively large by Santa Catarina standards.

The arbitrary cut-off point for variable selection for building the logistic regression model was the significance level of $\mathrm{p} \leq 0.20$ in the univariable analysis, as described in Table 4 . The variables that met this criterion were "number of females in the herd," "type of production," "type of milking," and "acquisition of females or males for reproduction." The variable "type of milking" was strongly associated with "type of production." Thus, only the variable, "type of production", was offered to the logistic regression model.

Table 4. Univariable analysis indicating variables with $p$-value $\leq 0.20$ when tested for the association with bovine TB-positive herds.

\begin{tabular}{|c|c|c|c|c|}
\hline Variable & & Cases & Controls & p-value ${ }^{1}$ \\
\hline \multirow[t]{3}{*}{ No. of females in the herd } & & & & 0.001 \\
\hline & Up to 18 females & 2 & 1,240 & \\
\hline & 19 or more females & 6 & 405 & \\
\hline \multirow[t]{3}{*}{ Type of production } & & & & 0.004 \\
\hline & Dairy & 6 & 474 & \\
\hline & Beef or Dual-purpose & 2 & 1,161 & \\
\hline \multirow[t]{4}{*}{ Number of milkings per day } & & & & 0.116 \\
\hline & No milking & 2 & 559 & \\
\hline & One milking & 0 & 382 & \\
\hline & Two or three milkings & 6 & 662 & \\
\hline \multirow[t]{5}{*}{ Type of milking } & & & & 0.000 \\
\hline & No milking & 2 & 528 & \\
\hline & $\begin{array}{l}\text { Mechanical milking in } \\
\text { parlor }\end{array}$ & 3 & 72 & \\
\hline & $\begin{array}{l}\text { Mechanical milking with } \\
\text { bucket }\end{array}$ & 3 & 268 & \\
\hline & Manual & 0 & 705 & \\
\hline \multirow{3}{*}{$\begin{array}{l}\text { Acquisition of females or males for } \\
\text { reproduction }\end{array}$} & & & & 0.187 \\
\hline & No & 3 & 979 & \\
\hline & Yes & 5 & 642 & \\
\hline
\end{tabular}

${ }^{1}$-value of chi-square test.

The variables that remained in the final model were "number of females in the herd" and "type of production," as shown in the model-based format (HOSMER et al., 2013) of logistic regression in Table 5. The odds of finding TB in herds with 19 or more females was 6.71 (95\% CI: 1.32-34.17) times higher than that in smaller herds; dairy herds showed an odds ratio (OR) of 5.13 (95\% CI: 1.01-
26.17) compared to beef or dual-purpose herds. The very wide CIs of the OR values reflected the small number of cases found. The likelihood ratio test was statistically significant ( $p$-value $=0.0012$ ), and the Hosmer-Lemeshow goodness-of-fit statistic demonstrated that there was evidence of agreement between the observed values of the outcome variable and the estimated probabilities of the outcome based 
on the model $(p$-value $=0.6547)$, thereby indicating that the model fit quite well (HOSMER et al., 2013). The area under the ROC curve, illustrated in Figure 3, was 0.8135 , which indicated a good overall capacity of the model to discriminate positive from negative herds for a series of cut-off points, as described by
Dohoo et al. (2010). The logistic regression model in the design-based format (HOSMER et al., 2013), considering the sample weights of properties by region, is detailed in Table 6 . This model yielded an OR for herds with 19 or more females of 7.68 (95\% CI: 1.22-48.39); for dairy herds the OR was 10.43 (95\% CI: 2.00-54.25).

Table 5. Logistic regression model for bovine tuberculosis in Santa Catarina, using the model-based method (HOSMER et al., 2013).

\begin{tabular}{llllc}
\hline Variable & & Odds Ratio & $\begin{array}{c}\text { 95\% Confidence } \\
\text { Interval }\end{array}$ & p-value \\
\hline Number of females in the herd & Up to 18 females & Reference & & 0.022 \\
& 19 or more females & 6.71 & 1.32 & 34.17 \\
Type of production & Beef or Dual-purpose & Reference & & \\
& Dairy & 5.13 & 1.01 & 26.17 \\
& & & & \\
\hline
\end{tabular}

Figure 3. Receiver operating characteristics (ROC) curve of the logistic regression model.

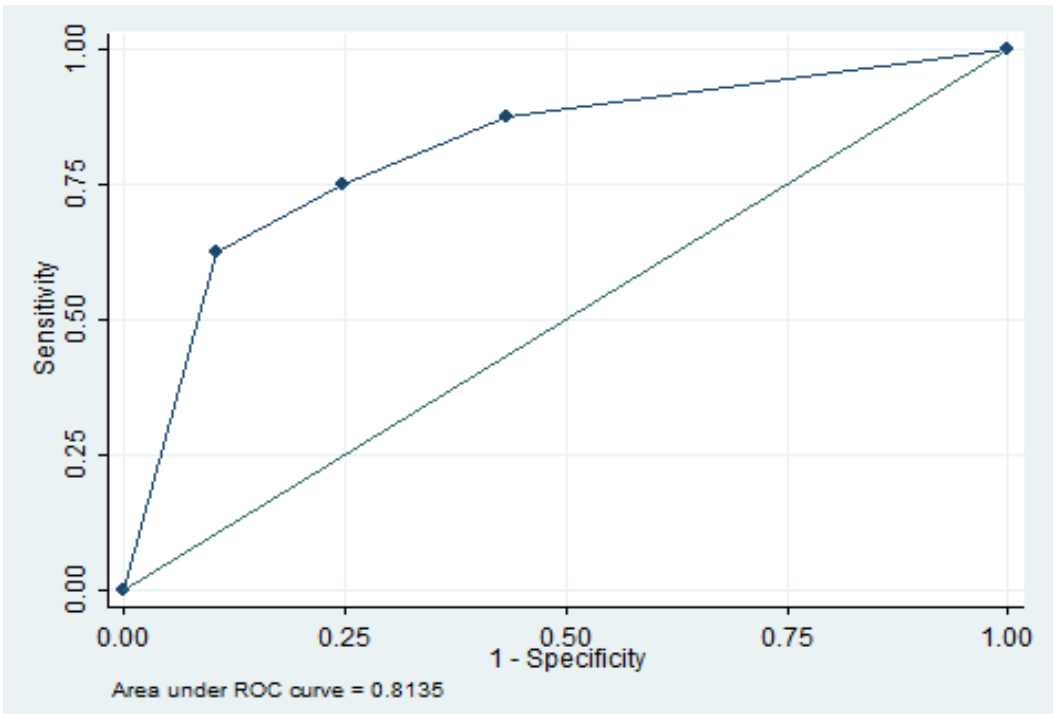


Table 6. Logistic regression model for bovine tuberculosis in Santa Catarina, using the design-based format (HOSMER et al., 2013).

\begin{tabular}{|c|c|c|c|c|c|}
\hline \multirow{2}{*}{$\begin{array}{l}\text { Variable } \\
\text { Number of females in the herd }\end{array}$} & & Odds Ratio & \multicolumn{2}{|c|}{$\begin{array}{l}\text { 95\% Confidence } \\
\text { Interval }\end{array}$} & p-value \\
\hline & & & & & 0.030 \\
\hline \multirow{5}{*}{ Type of production } & Up to 18 females & Reference & & & \multirow{5}{*}{0.005} \\
\hline & 19 or more females & 7.68 & 1.22 & 48.39 & \\
\hline & & & & & \\
\hline & Beef or Dual-purpose & Reference & & & \\
\hline & Dairy & 10.43 & 2.00 & 54.25 & \\
\hline
\end{tabular}

A comparison of the results of the two regression models showed that the risk variables were the same but the ORs were different, even though the magnitude of the values was similar. There was a considerable increase in sampling errors in the design-based model, as described in the literature (HOSMER et al., 2013). The interpretation of the OR was similar for both models, even though the design-based model was more appropriate for population inference, given that sampling was not proportional to size.

\section{Discussion}

The herd level prevalence of bovine TB in the state Santa Catarina was 0,50\% (95\% CI: 0,074$0,93 \%$ ) (Table 2), which is similar to the prevalence in the state of Mato Grosso, Mato Grosso do Sul and Distrito Federal, and lower than the prevalence in the state of São Paulo, Espírito Santo, Minas Gerais, Paraná, Rio Grande do Sul, Goiás, Rondônia, Bahia and Pernambuco (BAHIENSE et al., 2016; BARBIERI et al., 2016; DIAS et al., 2016; GALVIS et al., 2016; GUEDES et al., 2016; LIMA et al., 2016; NÉSPOLI et al., 2016; QUEIROZ et al., 2016; RIBEIRO et al., 2016; ROCHA et al., 2016; SILVA et al., 2016; VENDRAME et al., 2016).

The logistic regression models produced in design-based and model-based formats indicated dairy herds and larger herds (19 or more females) were risk factors for bovine TB in Santa Catarina. The design-based model is best suited for population inference, since it includes the weight of the herds sampled per region. In this study, each sampled herd in region 3 (west) represented 235.3 properties, while the primary sampling units in region 4 (north) represented only 41.8 herds, which stresses the importance of taking into account the sample weights in the study of risk factors. It should be noted that for model diagnostic purposes, the design-based format is more complex and the available techniques still need improvement (HOSMER et al., 2013). This justified the use of a simple model to evaluate the model fit and its predictive performance.

The risk factors found in this study are consistent with those observed in the states of Paraná, Bahia, São Paulo, Espírito Santo, Minas Gerais, Goiás and Rio Grande do Sul (BAHIENSE et al., 2016; BARBIERI et al., 2016; BELCHIOR et al., 2016; DIAS et al., 2016; GALVIS et al., 2016; QUEIROZ et al., 2016; ROCHA et al., 2016; SILVA et al., 2016). The results suggest that dairy herds, in which animals are kept in partial or total confinement, and larger herds, which tend to acquire animals more often, are at higher risk of bovine TB.

We found no statistically significant association between the occurrence of bovine TB and some of the variables that could be associated with disease dynamics, such as pasture rent, sharing of pasture with other properties, sharing of water sources and water troughs with other properties, presence of free-roaming wild animals, and existence of areas in which animals gathered. However, such a result may either reflect the low importance of some of 
these practices in Santa Catarina or the limitations of the statistical power of this study, given the small number of cases, which, according to Dohoo et al. (2010), can affect the estimation of parameters and statistical tests.

\section{Conclusions}

Given the low prevalence and type of herds most affected, a risk-based TB surveillance system should be developed for the dairy basins in the state, particularly for the western region that holds the major industries and more intensive dairy farms. In addition, we recommend that TB surveillance in Santa Catarina integrates case-control studies to better characterize the mechanisms of disease spread, including the flows and types of animal trade, and to identify risks that might underpin the planning of risk-based surveillance activities.

\section{Acknowledgements}

The authors acknowledge the logistical and financial support from MAPA, CIDASC, CNPq and FAPESP.

\section{References}

BAHIENSE, L.; ÁVILA, L. N. de; BAVIA, M. E.; AMAKU, M.; DIAS, R. A.; GRISI-FILHO, J. H. H.; FERREIRA, F.; TELLES, E. O.; GONÇALVES, V. S. P.; HEINEMANN, M. B.; FERREIRA NETO, J. S. Prevalence and risk factors for bovine tuberculosis in the State of Bahia, Brazil. Semina: Ciências Agrárias, Londrina, v. 37, n. 5, p. 3549-3560, 2016. Suplemento 2.

BARBIERI, J. M.; OLIVEIRA, L. F.; DORNELES, E. M. S.; MOTA, A. L. A. A.; GONÇALVES, V. S. P.; MALUF, P. P.; FERREIRA NETO, J. S.; FERREIRA, F.; DIAS, R. A.; TELLES, E. O.; GRISI-FILHO, J. H. H.; HEINEMANN, M. B.; AMAKU, M.; LAGE, A. P. Epidemiological status of bovine tuberculosis in the state of Minas Gerais, Brazil, 2013. Semina: Ciências Agrárias, Londrina, v. 37, n. 5, p. 3531-3548, 2016. Suplemento 2 .

BELCHIOR, A. P. C.; LOPES, L. B.; GONÇALVES, V. S. P.; LEITE, R. C. Prevalence and risk factors for bovine tuberculosis in Minas Gerais State, Brazil. Tropical Animal Health and Production, Edinburgh, v. 48, n. 2, p. 373-378, 2016.

BRASIL. Instrução Normativa $\mathrm{n}^{\circ} 2$, de 10 de janeiro de 2001. Aprova o Regulamento Técnico do Programa Nacional de Controle e Erradicação da Brucelose e Tuberculose Animal. Diário Oficial [da] União, Brasília, 16 jan. 2001. Disponível em: <http://sistemasweb. agricultura.gov.br/sislegis/action/detalhaAto. do?method $=$ detalharAtosArvore\&tipo $=I N M \&$ numero Ato $=00000002 \&$ seqA to $=000 \&$ valorAno $=2001 \&$ orgao $=$ SDA $/$ MAA\& $\operatorname{codTipo}=\&$ desItem $=\&$ desItemFim $=\#>$. Acesso em: 31 out. 2014.

.Instrução Normativan ${ }^{\circ}$ 6, de 08 de janeiro de 2004. Aprova o Regulamento Técnico do Programa Nacional de Controle e Erradicação da Brucelose e Tuberculose Animal. Diário Oficial [da] União, Brasília, 12 jan. 2004. Disponível em: <http://sistemasweb.agricultura. gov.br/sislegis/action/detalhaAto.do?method= detalhar AtosArvore \& tipo $=I N M \&$ numeroA to $=00000006 \&$ seq $A$ to $=000 \&$ valorAno $=2004 \&$ orgao $=$ SDA $/$ MAA\& $\operatorname{codTip}$ $\mathrm{o}=\&$ desItem $=\&$ desItemFim $=\&$ nomeTitulo $=\#>$. Acesso em: 31 out. 2014.

Programa Nacional de Controle e Erradicação da Brucelose e da Tuberculose Animal (PNCEBT): manual técnico. Ministério da Agricultura Pecuária e Abastecimento, Brasília: MAPA/SDA/DSA, 2006. p. 188.

CONSELHOS REGIONAIS DE MEDICINA VETERINÁRIA DO PARANÁ, SANTA CATARINA E RIO GRANDE DO SUL - CRMV/PR, CRMV/SC e CRMV/RS. Manual de Zoonoses. [S.1.: s.n.], 2009. v. 1, p. $142-161$.

DATA ANALYSIS AND STATISTICAL SOFTWARE - STATA MP 12. Stata: Release 12. Data analysis and statistical software. College Station, TX: StataCorp LP. 2014.

DIAS, R. A.; STANOJLOVIC, F. M. U.; BELCHIOR, A. P. C.; FERREIRA, R. S.; GONÇALVES, R. C.; AGUIAR, R. S. C. B.; SOUSA, P. R.; SANTOS, A. M. A.; AMAKU, M.; FERREIRA, F.; TELLES, E. O.; GRISI-FILHO, J. H. H.; GONÇALVES, V. S. P.; HEINEMANN, M. B.; FERREIRA NETO, J. S. Prevalence and risk factors for bovine tuberculosis in the state of São Paulo, Brazil. Semina: Ciências Agrárias, Londrina, v. 37, n. 5, p. 3673-3684, 2016. Suplemento 2.

DOHOO, I.; MARTIN, W.; STRYHN, H. Veterinary epidemiologic research. $2^{\text {th }}$ ed. Charlottetown: University of Prince Edward Island, 2010. 865 p. 
EMPRESA BRASILEIRA DE PESQUISA AGROPECUÁRIA - EMBRAPA. Centro Nacional de Pesquisa de Gado de Leite. Ranking da produção de leite por Estado, 2010/2011. 2012. Disponível em: <http:// www.cnpgl.embrapa.br/nova/informacoes/estatisticas/ producao/tabela0240.php>. Acesso em: 03 abr. 2014.

GALVIS, J. O. A.; GRISI-FILHO, J. H. H; COSTA, D.; SAID, A. L. P. R.; AMAKU, M.; DIAS, R. A.; FERREIRA, F.; GONÇALVES, V. S. P.; HEINEMANN, M. B.; TELLES, E. O.; FERREIRA NETO, J. S. Epidemiologic characterization of bovine tuberculosis in the state of Espírito Santo, Brazil. Semina: Ciências Agrárias, Londrina, v. 37, n. 5, p. 3567-3578, 2016. Suplemento 2.

GUEDES, I. B.; BOTTENE, I. F. N.; MONTEIRO, L. A. R. C.; LEAL FILHO, J. M.; HEINEMANN, M. B.; AMAKU, M.; GRISI-FILHO, J. H. H.; DIAS, R. A.; FERREIRA, F.; TELLES, E. O.; GONÇALVES, V. S. P.; FERREIRA NETO, J. S. Prevalence and risk factors for bovine tuberculosis in the state of Mato Grosso do Sul, Brazil. Semina: Ciências Agrárias, Londrina, v. 37, n. 5, p. 3579-3588, 2016. Suplemento 2.

HOSMER, D. W. J.; LEMESHOW, S.; STURDIVANT, R. X. Applied logistic regression. $3^{\text {th }}$ ed. New Jersey: Wiley, 2013. 500 p.

INSTITUTO BRASILEIRO DE GEOGRAFIA E ESTATÍSTICA - IBGE. Estados@ - Santa Catarina: Pecuária 2012. 2014c. Disponível em: <http://www. ibge.gov.br/estadosat/temas. php?sigla $=$ sc\&tema $=$ pecua ria2012>. Acesso em: 12 dez. 2014.

Estados@ - Santa Catarina: Síntese. 2014a. Disponível em: <http://www.ibge.gov.br/estadosat/perfil. php?sigla=sc\#>. Acesso em: 12 dez. 2014.

Indicadores IBGE: Estatística da produção pecuária - Dezembro de 2014. 2014b. Disponível em: $\quad<$ http://www.ibge.gov.br /estadosat/perfil. php?sigla=sc\#>. Acesso em: 12 dez. 2014.

LIMA, P. B.; NASCIMENTO, D. L.; ALMEIDA, E. C.; PONTUAL, K. A. Q.; AMAKU, M.; DIAS, R. A.; FERREIRA, F.; GONÇALVES, V. S. P.; TELLES, E. O.; GRISI-FILHO, J. H. H.; HEINEMANN, M. B.; SILVA, J. C. R.; FERREIRA NETO, J. S. Epidemiological situation of bovine tuberculosis in the state of Pernambuco, Brazil. Semina: Ciências Agrárias, Londrina, v. 37, n. 5, p. 3601-3610, 2016. Suplemento 2.

LIVINGSTONE, P. G.; RYAN, T. J.; HANCOX, N. G.; CREWS, K. B.; BOSSON, M. A. J.; KNOWLES, G. J. E.; McCOOK, W. Regionalisation: a strategy that will assist with bovine tuberculosis control and facilitate trade. Veterinary Microbiology, Amsterdam, v. 112, n. 2006, p. 291-301, 2006.
LÔBO, J. R. Análise custo-benefício da certificação de propriedades livres de tuberculose bovina. 2008. Dissertação (Mestrado em Agronegócios) - Universidade de Brasília, Brasília.

NÉSPOLI, J. M. B.; NEGREIROS, R. L.; AMAKU, M.; DIAS, R. A.; FERREIRA, F.; TELLES, E. O.; HEINEMANN, M. B.; GRISI-FILHO, J. H. H.; GONÇALVES, V. S. P.; FERREIRA NETO, J. S. Epidemiological situation of bovine tuberculosis in the state of Mato Grosso, Brazil. Semina: Ciências Agrárias, Londrina, v. 37, n. 5, p. 3589-3600, 2016. Suplemento 2.

NEVES, B. M. C. Caracterização produtiva e aspectos sanitários relacionados à bovinocultura em Santa Catarina. 2014. Dissertação (Mestrado em Saúde Animal) - Faculdade de Agronomia e Medicina Veterinária, Universidade de Brasília, Brasília.

PETRIE, A.; WATSON, P. Estatística em ciência animal e veterinária. $2^{\text {th }}$ ed. São Paulo: Roca, 2009. 236 p.

QUANTUM GIS DEVELOPMENT TEAM - QGIS. Quantum GIS geographic information system. Open Source Geospatial Foundation Project. 2012. Available at: <http://qgis.osgeo.org/>. Accessed at: 11 Dec 2014.

QUEIROZ, M. R.; GROFF, A. C. M.; SILVA, N. S.; GRISI-FILHO, J. H. H.; AMAKU, M.; DIAS, R. A.; TELLES, E. O.; HEINEMANN, M. B.; FERREIRA NETO, J. S.; GONÇALVES, V. S. P. FERREIRA, F. Epidemiological status of bovine tuberculosis in the state of Rio Grande do Sul, Brazil. Semina: Ciências Agrárias, Londrina, v. 37, n. 5, p. 3647-3658, 2016. Suplemento 2.

RIBEIRO, L. A.; GONÇALVES, V. S. P.; FRANCISCO, P. F. C.; MOTA, A. L. A. A.; NASCIMENTO, G. T.; LICURGO, J. B.; FERREIRA, F.; GRISI-FILHO, J. H. H.; FERREIRA NETO, J. S.; AMAKU, M.; DIAS, R. A.; TELLES, E. O.; HEINEMANN, M. B.; BORGES, J. R. J. Epidemiological status of bovine tuberculosis in the Federal District of Brazil. Semina: Ciências Agrárias, Londrina, v. 37, n. 5, p. 3561-3566, 2016. Suplemento 2.

ROCHA, W. V.; JAYME, V. S.; MOTA, A. L. A. A.; BRITO, W. M. E. D; PIRES, G. R. C; GRISI-FILHO, J. H. H; DIAS, R. A.; AMAKU, M.; TELLES, E. O.; HEINEMANN, M. B.; FERREIRA, F.; FERREIRA NETO, J. S.; GONÇALVES, V. S. P. Prevalence and herd-level risk factors of bovine tuberculosis in the State of Goiás, Brazil. Semina: Ciências Agrárias, Londrina, v. 37, n. 5, p. 3625-3628, 2016. Suplemento 2.

ROTHMAN, K. J.; GREENLAND, S.; LASH, T. L. Modern epidemiology. $3^{\text {th }}$ ed. Philadelphia: Lippincott Williams \& Wilkins, 2008. 751 p.

SERGEANT, E. S. G. Epitools epidemiological calculators. AusVet Animal Health Services and 
Australian Biosecurity Cooperative Research Centre for Emerging Infectious Disease. 2014. Available at: $<$ http:// epitools.ausvet.com.au>. Access at: 22 May 2014.

SILVA, M. C. P.; GONÇALVES, V. S. P.; MOTA, A. L. A. A.; KOLODA, M.; FERREIRA NETO, J. S.; GRISIFILHO, J. H. H; DIAS, R. A.; AMAKU, M.; TELLES, E. O.; FERREIRA, F.; HEINEMANN, M. B.; ALFIERI, A. A.; MULLER, E. E. Prevalence and herd-level risk factors for bovine tuberculosis in the state of Paraná, Brazil. Semina: Ciências Agrárias, Londrina, v. 37, n. 5, p. 3611-3624, 2016. Suplemento 2.

SKUCE, R. A.; ALLEN, A. R.; McDOWELL, W. J. Herdlevel risk factors for bovine tuberculosis: a literature review. Veterinary Medicine International, New York, v. 2012, n. x, p. 1-10, 2012.
VENDRAME, F. B.; AMAKU, M.; FERREIRA, F; TELLES, E. O.; GRISI-FILHO, J. H. H.; GONÇALVES, V. S. P.; HEINEMANN, M. B.; FERREIRA NETO, J. S.; DIAS, R. A. Epidemiologic characterization of bovine tuberculosis in the State of Rondônia, Brazil. Semina: Ciências Agrárias, Londrina, v. 37, n. 5, p. 3639-3646, 2016. Suplemento 2.

WORD ORGANISATION FOR ANIMAL HEALTH - OIE. List of FMD free member countries (according to Resolution $\mathrm{n}^{\mathrm{o}} 15$ - 82nd general session May 2014): FMD free zone where vaccination is not practiced. 2014. Available in: <http://www.oie.int/en/animal-health-inthe-world/official-disease-status/fmd/list-of-fmd-freemembers/>. Accessed at: 11 Dec 2014. 